\title{
Identification of optimal regions for phylogenetic studies on VP1 gene of foot-and-mouth disease virus: analysis of types $A$ and $O$ Argentinean viruses
}

\author{
Jose I. NúñEZ ${ }^{\mathrm{a}, \mathrm{b}}$, Maria J. MARTín ${ }^{\mathrm{c}}$, Maria E. PiCCONE ${ }^{\mathrm{d}}$, \\ Elisa CARrILlO ${ }^{\mathrm{d}}$, Eduardo L. PALMA ${ }^{\mathrm{d}}$, Joaquin DOPAZO ${ }^{\mathrm{e} * *}$, \\ Francisco SOBRINO ${ }^{a * b}$
}

a Centro de Biología Molecular "Severo Ochoa" (CSIC-UAM), Cantoblanco 28049, Madrid, Spain
b Centro de Investigación en Sanidad Animal, INIA, Valdeolmos 28130, Madrid, Spain
c EBI, Hinxton, Cambridge CB10, UK
1780 Morón, Buenos Aires, Argentina
d Instituto de Biotecnología, Centro de Investigación en Ciencias Veterinarias, INTA,
e Research Department, Glaxo Wellcome S.A., PTM, c/Severo Ochoa 2, 28760 Tres Cantos, Spain

(Received 9 March 2000; accepted 18 September 2000)

\begin{abstract}
An analysis of the informative content of sequence stretches on the foot-and-mouth disease virus (FMDV) VP1 gene was applied to two important viral serotypes: A and O. Several sequence regions were identified to allow the reconstruction of phylogenetic trees equivalent to those derived from the whole VP1 gene. The optimal informative regions for sequence windows of 150 to $250 \mathrm{nt}$ were predicted between positions 250 and 550 of the gene. The sequences spanning the $250 \mathrm{nt}$ of the 3 ' end (positions 400 to 650), extensively used for FMDV phylogenetic analyses, showed a lower informative content. In spite of this, the use of sequences from this region allowed the derivation of phylogenetic trees for type A and type O FMDVs which showed topologies similar to those previously reported for the whole VP1 gene. When the sequences determined for viruses isolated in Argentina, between 1990 and 1993, were included in these analyses, the results obtained revealed features of the circulation of type $\mathrm{A}$ and type $\mathrm{O}$ viruses in the field, in the months that preceded the eradication of the disease in this country. Type A viruses were closely related to an Argentinean vaccine strain, and defined an independent cluster within this serotype. Among the type $\mathrm{O}$ viruses analysed, two groups were distinguished; one was closely related to the South American vaccine strains, while the other was grouped with viruses of the $\mathrm{O} 3$ subtype. In addition, a detailed phylogeny for type A FMDV is presented.
\end{abstract}

foot-and-mouth disease virus / phylogenetic analysis / informative region / molecular epidemiology

* Correspondence and reprints

Tel.: (34) 91 6202300; fax: (34) 91 6202247; e-mail: fsobrino@cnb.uam.es

**Present address: Bioinformatics Unit, Centro Nacional de Investigaciones Oncológicas, Ctra

Majadahonda Pozuelo Km 2, Majadahonda 28220, Spain. 
Résumé - Identification des régions optimales pour les études phylogénétiques du gène VP1 du virus de la fièvre aphteuse : analyse des virus argentins de types $\mathbf{A}$ et $O$. Une analyse du contenu informatif de parties de séquences du gène VP1 du virus de la fièvre aphteuse (VFA) a été appliquée à deux sérotypes viraux importants : A et $\mathrm{O}$. Plusieurs régions de séquences ont été identifiées afin de permettre la reconstruction d'arbres phylogénétiques équivalents à ceux obtenus à partir de gène VP1 entier. Les régions informatives optimales pour des fenêtres de séquences de 150 à $250 \mathrm{nt}$ ont été supposées être comprises entre les positions 250 et 550 du gène. Les séquences recouvrant les $250 \mathrm{nt}$ de l'extrémité 3' (positions 400 à 650), qui ont été largement utilisées pour les études phylogénétiques du VFA, avaient un contenu moins informatif. Malgré cela, l'utilisation de séquences de cette région a permis d'obtenir des arbres phylogénétiques pour les VFA de type A et $\mathrm{O}$, qui ont montré des topologies similaires à celles précédemment décrites pour le gène VP1 entier. Quand les séquences déterminées pour les virus isolés en Argentine entre 1990 et 1993 ont été incluses dans ces analyses, les résultats obtenus ont révélé des caractéristiques de circulation des virus de type $\mathrm{A}$ et $\mathrm{O}$ sur le terrain, dans les mois qui ont précédé l'éradication de la maladie dans ce pays. Les virus de type A étaient étroitement apparentés à une souche argentine de vaccin et définissaient un groupe indépendant à l'intérieur de ce sérotype. Parmi les virus de type $\mathrm{O}$ analysés, nous avons pu distinguer deux groupes : 1'un était étroitement apparenté aux souches vaccinales sud-américaines, l'autre était proche des virus du sous-type O3. Une phylogénie détaillée du VFA type A est également présentée.

virus de la fièvre aphteuse / analyse phylogénétique / région informative / épidémiologie moléculaire

\section{INTRODUCTION}

The nucleotide (nt) sequencing of informative genomic regions and the use of these sequences for phylogenetic analysis is becoming an approach widely employed in the epidemiological study of most human and animal pathogens. This is the case for the foot-and-mouth disease virus (FMDV), an aphthovirus within the Picornaviridae family that is the causative agent of the most transmissible animal disease [28]. The threat represented by FMD was recently illustrated by the outbreak that occurred in Taiwan in 1997, in which over 3 million animals were slaughtered [14]. The importance of an accurate characterisation of the viruses causing FMD outbreaks is due to the high antigenic polymorphism exhibited by the virus, which is reflected in seven serotypes and a multitude of variants [7], as well as by the need for adequate vaccines to be used for disease control of the circulating viruses [15]. Therefore, nt sequencing analysis has become an important tool for the characterisation of FMD outbreaks [1]. These analyses have mainly been focused on the gene encoding the VP1 capsid protein, since it is highly polymorphic and plays a relevant role in the antigenicity of the viral particle [9]. The approach has revealed the patterns of field evolution of different viral serotypes, as well as the origin of viruses responsible for recent outbreaks [3, 10, 24, 33, 38]. In addition, and for practical reasons, sequencing of the 200-250 nt from the 3' end of the VP1 gene - either from viral RNA or, more recently, from RT-PCR amplified cDNAs - has become a complement to the serology in the characterisation of field isolates. In this way, a significant amount of information is available for type O, A, C, Asia and SAT 1 and 2 serotypes [6, 21, 27, 34, 35]. However, a detailed analysis of the informative content of this region in viruses of different serotypes, with respect to the whole VP1 gene, has not been performed. The use of a procedure to predict sequence stretches with an informative content similar to that of the complete gene has recently allowed to report that phylogenetic trees derived from the 200 or 250 3'end nt of type C VP1 genes are equivalent to those obtained from the whole molecule [22]. In this report we have 
extended this analysis to the VP1 gene of serotypes $\mathrm{A}$ and $\mathrm{O}$, responsible for most of the viral outbreaks in Europe and South America. Even when the $250 \mathrm{nt}$ from the 3 ' end were not predicted to contain the higher informative value within the VP1 gene, they allowed the construction of trees topologically similar to those obtained from the whole gene. Using this approach, we have extended the phylogenetic analyses of FMDVs of serotypes $\mathrm{A}$ and $\mathrm{O}$, including viruses isolated in Argentina during the period from 1990-1993, previous to the eradication of the disease.

\section{MATERIALS AND METHODS}

\subsection{Viruses}

The Argentinean FMDV isolates analysed in this work are detailed in Table I. These viruses were collected from lesions of infected animals and passaged twice in BHK-21 cells.

\subsection{Identification of optimal regions for phylogenetic analyses}

This analysis was performed using a heuristic method previously reported [22], designed to detect partial sequence regions that contain phylogenetic information comparable to that of the complete gene sequence. To achieve this, we (i) selected a set of sequences of the target gene that were representative of the genetic spectrum of the group whose analysis was intended, since they included sequences from viruses of different subtypes within each of the serotypes analysed, (ii) calculated the pairwise genetic distances corresponding to the reference group of sequences, and (iii) compared it with those genetic distances obtained with windows of variable sizes and positions along the gene. This approach measures the agreement in the informative content of local windows to the total informative content of the whole gene sequences whose analysis is intended. The summation of the entry to entry differences, between the global distance matrix, obtained from the whole length sequences, and the local matrix, obtained from local windows is related to the informative contents of these windows. The lower this divergence value is, the closer both matrices are and, consequently, the higher is the probability of obtaining the same phylogenetic tree from them.

In this report, the method has been applied to the analysis of the VP1 gene nucleotides from FMDV isolates of

Table I. Argentinean FMDV isolates analysed in this work.

\begin{tabular}{lccc}
\hline Virus & Isolation place & Province & Date \\
\hline Serotype A: & & & 1990 \\
A Ayacucho Arg/90 & Ayacucho & Buenos Aires & 1990 \\
A Robles Arg/90 & Robles & Santiago del Estero & 1993 \\
A Saavedra Arg/93 & Saavedra & Buenos Aires & 1993 \\
A 911 Arg/93 & unknow & & 1993 \\
A 059 Arg/93 & unknow & & 1993 \\
Serotype O: & & La Pampa & 1993 \\
O Atreuco Arg/93 & Atreuco & Córdoba & 1993 \\
O Córdoba Arg/93 & Marcos Juares & & 1993 \\
O Villarino Arg/93 & Villarino & & \\
O 397 Arg/93 & unknow & & \\
\hline
\end{tabular}


serotypes $\mathrm{A}$ and $\mathrm{O}$. The set of reference sequences selected, shown in Table II, included reference strains and field isolates from viruses of those FMDV subtypes for which the complete VP1 nucleotide sequence is available in the data bases.

\subsection{VP1 RNA sequencing}

Virus RNAs were phenol extracted from the supernatants recovered from BHK-21 cells infected with the viral isolates. The RNAs were copied into cDNA using reverse transcriptase and the VP1 sequences were amplified using Taq poly- merase, as previously described [36]. As schematically represented in Figure 1, type A VP1 RNAs were RT-PCR amplified using oligonucleotides (numbering in 5' -3 ', according to [39]): d, GAAGGGCCCAGGGTTGGACT (complementary to positions 35 to 54 of the $2 \mathrm{AB}$ gene) and V-9 TGAGTCCCACACATGTCA (spanning positions 134 to 151 of the VP1 gene). Type O RNA amplification was performed using oligonucleotides (numbering according to [5]): $d$ and V-27, GATTTGTGAAGGTGACACC (spanning positions 113 to 131 of the VP1 gene). The amplified cDNAs were directly sequenced using an fmol sequencing kit (Promega), as

Table II. VP1 FMDV sequences used in this work.

\begin{tabular}{|c|c|c|}
\hline Virus & Identification number ${ }^{\mathrm{a}}$ & Reference \\
\hline 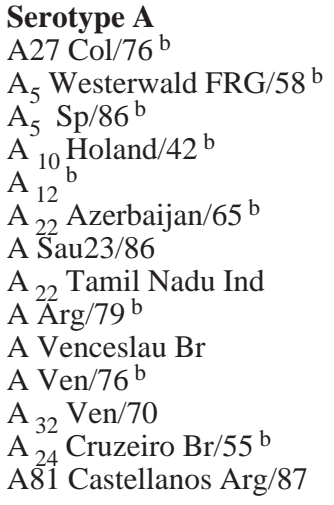 & $\begin{array}{c}\text { FMDVA27 } \\
\text { FMDVA5 } \\
\text { APHVP1AAA } \\
\text { APHA10VP } \\
\text { APHA12CD } \\
\text { FMDVA22 } \\
\text { APHVP1AF } \\
\text { FMDVA22C2 } \\
\text { FMDVA79 } \\
\text { APHVP1A } \\
\text { FMDVA76 } \\
\text { FMDVA32 } \\
\text { PIA24VP } \\
\text { U62255 }\end{array}$ & $\begin{array}{c}{[39]} \\
{[39]} \\
{[32]} \\
{[37]} \\
{[30]} \\
{[39]} \\
{[34]} \\
\text { (unpublished) } \\
{[39]} \\
{[5]} \\
{[39]} \\
{[39]} \\
{[20]} \\
{[26]}\end{array}$ \\
\hline 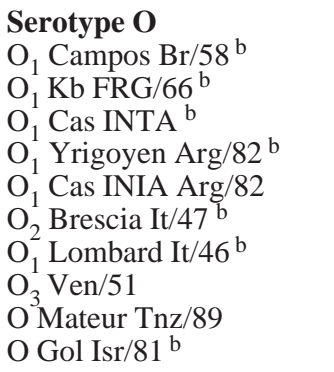 & $\begin{array}{l}\text { M95781 } \\
\text { X00871 } \\
\text { APHVPI } \\
\text { Z21862 } \\
\text { Z21861 } \\
\text { M55287 } \\
\text { M58601 } \\
\text { FVAJ4645 } \\
\text { Z21859 } \\
\text { Z21860 }\end{array}$ & $\begin{array}{c}\text { (unpublished) } \\
{[12]} \\
{[29]} \\
{[33]} \\
{[33]} \\
{[17]} \\
{[18]} \\
{[19]} \\
{[33]} \\
{[33]}\end{array}$ \\
\hline
\end{tabular}

${ }^{a}$ EMBL/Gene bank accesion number.

${ }^{\mathrm{b}}$ Sequences used for the analysis of the informative content of sequence stretches in VP1 gene (see Materials and Methods). 
FMDV RNA

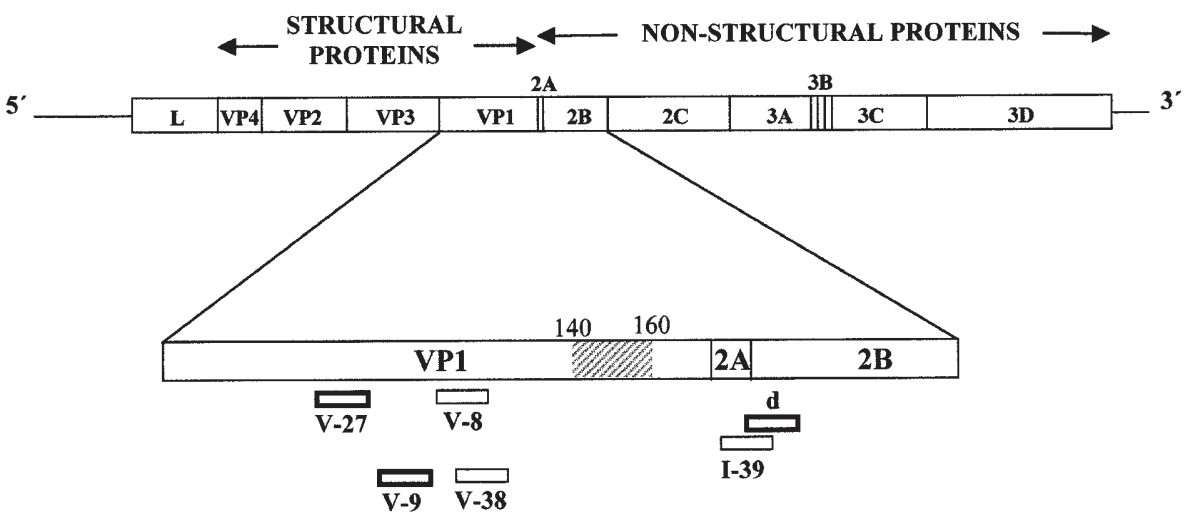

Figure 1. Location on FMDV RNA of the VP1 and 2AB genes and the primers used in this study. The nucleotide positions spanned by each primer are shown in Materials and Methods. $\square$ indicate primers used for RT-PCR amplification; $\square$ denote primers used for cDNA sequencing. The region corresponding to amino acid residues $140-160$ is hatched.

previously described [36]. The following internal primers were used for type A cDNA sequencing: I-39, GACTCAACGTCACCCGCCAAC (complementary to positions 18 to 38 of the $2 \mathrm{AB}$ gene) and V-38, CCCCACTGCCTACAACAAGG (spanning positions 309 to 328 of the VP1 gene). For type O, oligonucleotides I-39 and V-8, TGGACAACACCACCAACCCA (spanning positions 293 to 312 of the VP1 gene) were used.

\subsection{Phylogenetic analyses}

The VP1 sequences determined were aligned with those of isolates representative of the FMDV serotypes A and $\mathrm{O}$ (see Tab. II), using the CLUSTAL V program [13]. Phylogenetic trees were obtained using the neighbour-joining method [31], and were a consensus of 1000 bootstrap replicates [11].

\section{RESULTS}

\subsection{Informative regions within the VP1 gene sequence of FMDV $A$ and $O$ serotypes}

In this report, we identified stretches on the VP1 gene from two important FMDV serotypes: $\mathrm{A}$ and $\mathrm{O}$, that contained phylogenetic information comparable to that of the complete gene. The informative content of windows of 150, 200 and $250 \mathrm{nt}$ in length along the molecule was determined following the procedure described in Materials and Methods. The results are summarised in Figure 2, in which the profiles represent the divergence in informative content of the windows whose 5 ' end $\mathrm{nt}$ is indicated on the $x$-axis. In type $\mathrm{O}$, the most informative windows of 150 and $200 \mathrm{nt}$ length started around positions 200 to 300 , while windows of $250 \mathrm{nt}$ length showed a wider optimum 


\section{Type A}

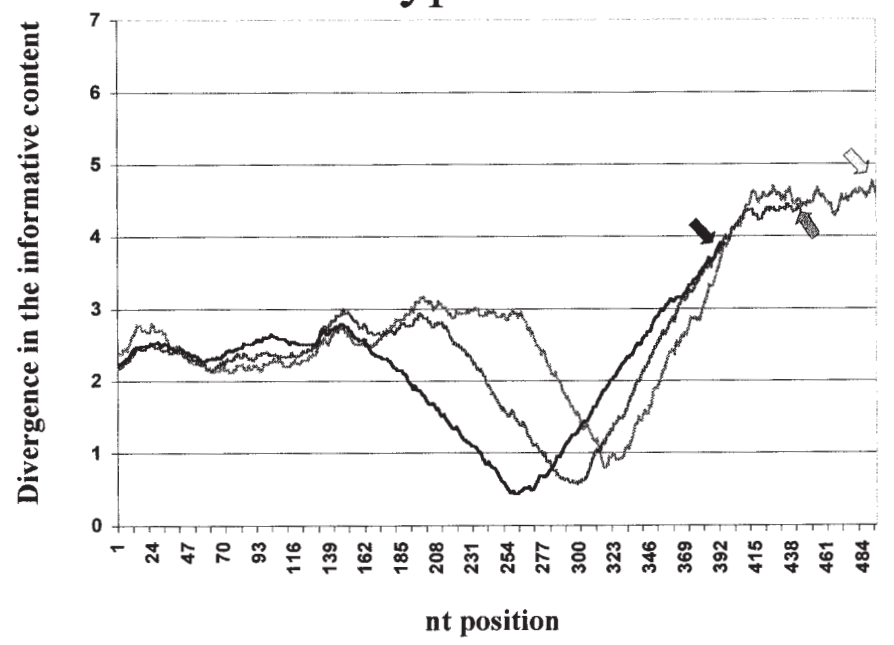

\section{Type O}

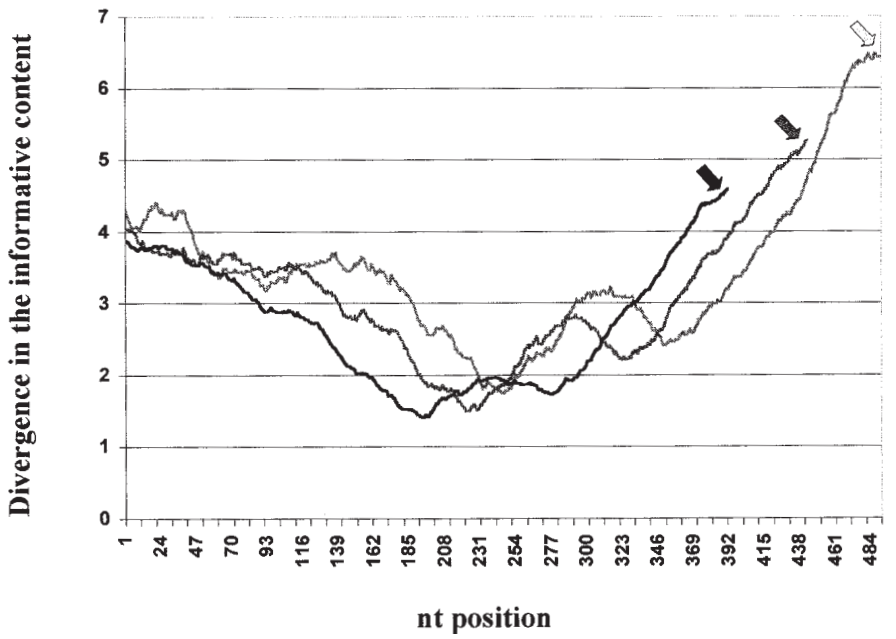

Figure 2. Plots of the divergence in the informative content of windows of different length in VP1 genes of serotypes $\mathrm{A}$ and $\mathrm{O}$. The plots were obtained from the sequences indicated in Table II (see Materials and Methods for details), as described in [22]. The results obtained for windows of 150 (light grey), 200 (dark grey) and 250 (black) nt long, are shown. The values in the $y$-axis represent the divergence in the informative content, that is defined as the relative differences between the distance matrices obtained using the whole VP1 gene and the distance matrices obtained using only windows starting at a position specified in the horizontal axis, spanning 150, 200 or $250 \mathrm{nt}$. As the differences between both matrices decrease, the likelihood of obtaining a wrong phylogenetic tree, different from the one obtained using the complete VP1 sequence, is lower. In this case, windows within the size 200 to 250 , starting between positions $350-400$, seems to provide the choice with the most informative content. Arrows point the informative content of each of the most 3' end windows analysed. 
from positions 150 to 300 . For type A, the optimum region was narrower and included windows starting from positions 310 to 330 (for $150 \mathrm{nt}$ length), 260 to 340 (for $200 \mathrm{nt}$ length) and 230 to 300 (250 nt length). The divergence in the informative content of the windows corresponding to 150,200 or $250 \mathrm{nt}$ from the 3 ' end, is indicated with an arrow in Figure 2. The divergence values of these regions were lower than those of windows starting in the middle of the molecule.

\subsection{Phylogenetic analysis of type $A$ FMDV, including Argentinean isolates previous to FMD eradication}

To asses the reliability of the phylogenetic trees derived from the VP1 3' end region, trees were obtained using previously reported type A sequences, as well as sequences from Argentinean field isolates that were determined in this work. Thus, the $250 \mathrm{nt}$ of the 3' end of the VP1 gene of the Argentinean isolates detailed on Table I, were RT-PCR amplified and sequenced, as described in Materials and Methods. These sequences were aligned with those of viruses representative of this serotype, shown in Table II. The phylogenetic tree derived from this alignment (Fig. 3-2) showed two independent lineages. The European viruses, including isolates of subtypes A5, A10 and A12, appeared in lineage A. Lineage, B, was more diversified and two additional clusters could be distinguished. The main of these clusters included most of the South American reference and vaccine strains. Interestingly, this cluster contained, also, Asian isolates as A 22 Azerbaijan/65 and A Sau23/86. On the contrary, all the Argentinean viruses analysed were located in the second cluster of lineage B, closely related to the A81 Castellanos Arg/87 vaccine strain. These viruses defined an independent and related group of sequences.
The amino acid sequences derived from the Argentinean nt sequences were also compared with those of the isolates used to construct the phylogenetic tree. Amino acid substitutions were found along the 84 residues compared, with a considerable number of substitutions affecting residues around positions 140-160 that define an important B cell antigenic site in serotype A (Fig. 4).

\subsection{Analysis of type $O$ Argentinean isolates}

A similar analysis was performed with four type $\mathrm{O}$ viruses, isolated from different locations during 1993. The $250 \mathrm{nt}$ of the 3 ' end of the VP1 gene from isolates O Cordoba Arg/93, O Villarino Arg/93, O Atreuco Arg/93 and O 397 Arg/93 were determined and aligned with those of the isolates representative of this serotype (see Tab. II). Two main lineages were noticed in the tree derived from these sequences, Fig. 5-2. Lineage $\mathrm{B}$ contained isolates from Africa and the Middle-East (i.e. O Gol Isr/81). Lineage A showed a more branched pattern, in which four defined clusters could be distinguished. Three of the Argentinean viruses, O Cordoba Arg/93, O Villarino Arg/93 and O Atreuco Arg/93, were grouped within a cluster (i), closely related to the Brazilian O1 Campos Br/58 strain, as well as the European O1 Kb FRG/66 reference strain. The O 397 Arg/93 isolate resulted in a different cluster (iv), related to the $\mathrm{O} 3 \mathrm{Ven} / 51$ isolate, a virus belonging to a different serological subtype. Thus, the viruses that circulated in Argentina in 1993 included isolates from two independent and serologically different subtypes.

The amino acid substitutions found among the type O VP1 analysed sequences, were preferentially accumulated around positions 140-160, and were also observed at the carboxyterminus of the molecule (see Fig. 6). 
1)

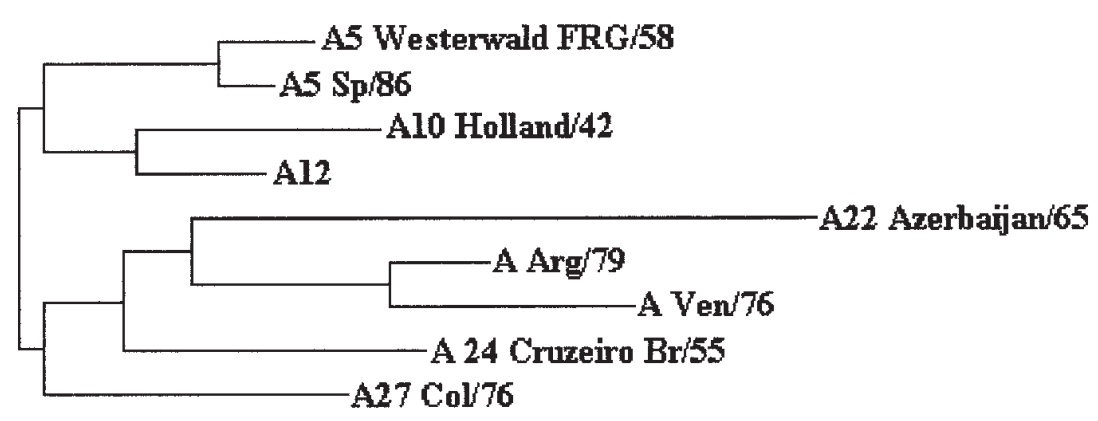

$\begin{array}{lll}0.1 & 0.0\end{array}$

2)
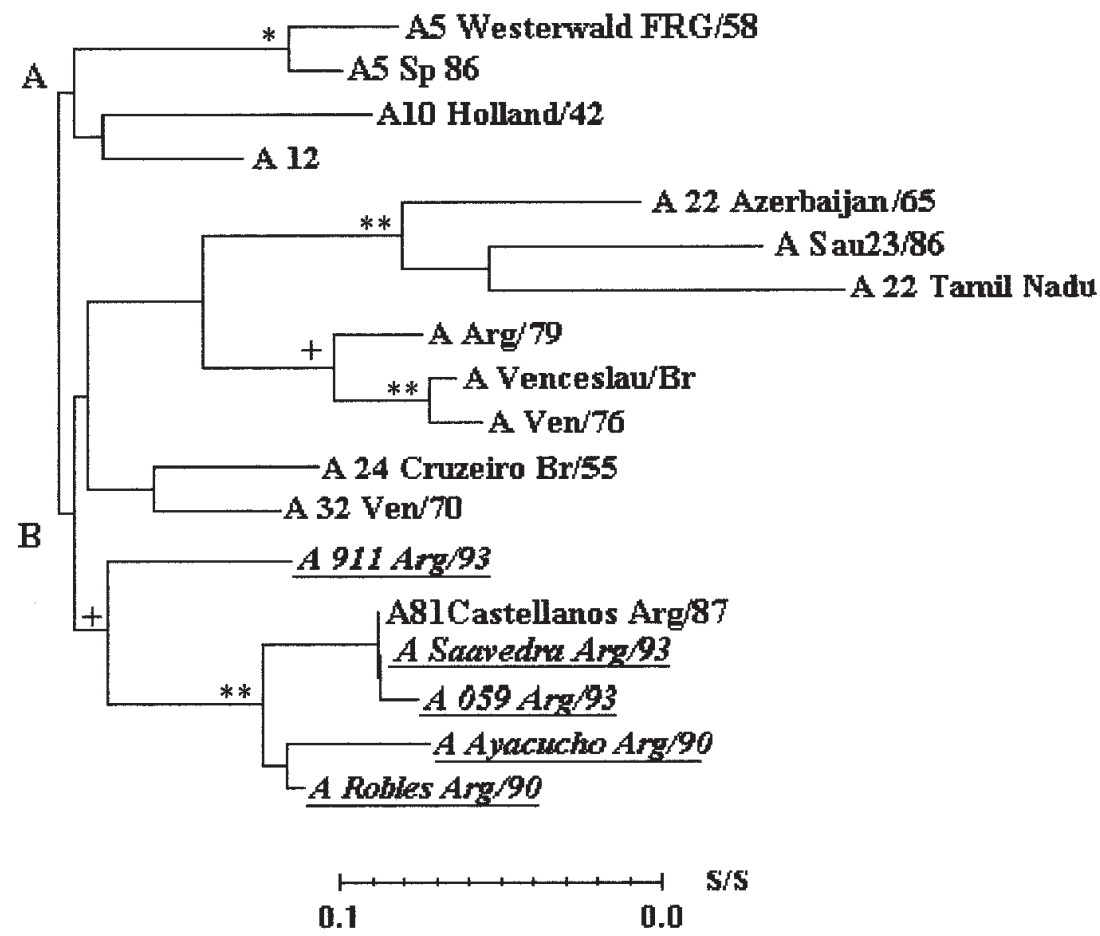

Figure 3. Phylogenetic trees derived from the type A VP1 gene sequences. (1) Tree corresponding to the whole VP1 gene (adapted from [23]). (2) Tree derived from the $250 \mathrm{nt}$ of the 3' end of type A VP1 sequences, including the Argentinean sequences determined in this work (underlined). The details on the construction of the trees are given in Materials and Methods. Vertical distances are arbitrary, but horizontal distances represent the number of nt substitutions per site (S/S). Symbols for statistical significance levels for branching points obtained by bootstrap are $(+)>90 \% ;(*)>95 \% ;(* *)>99 \%$. 


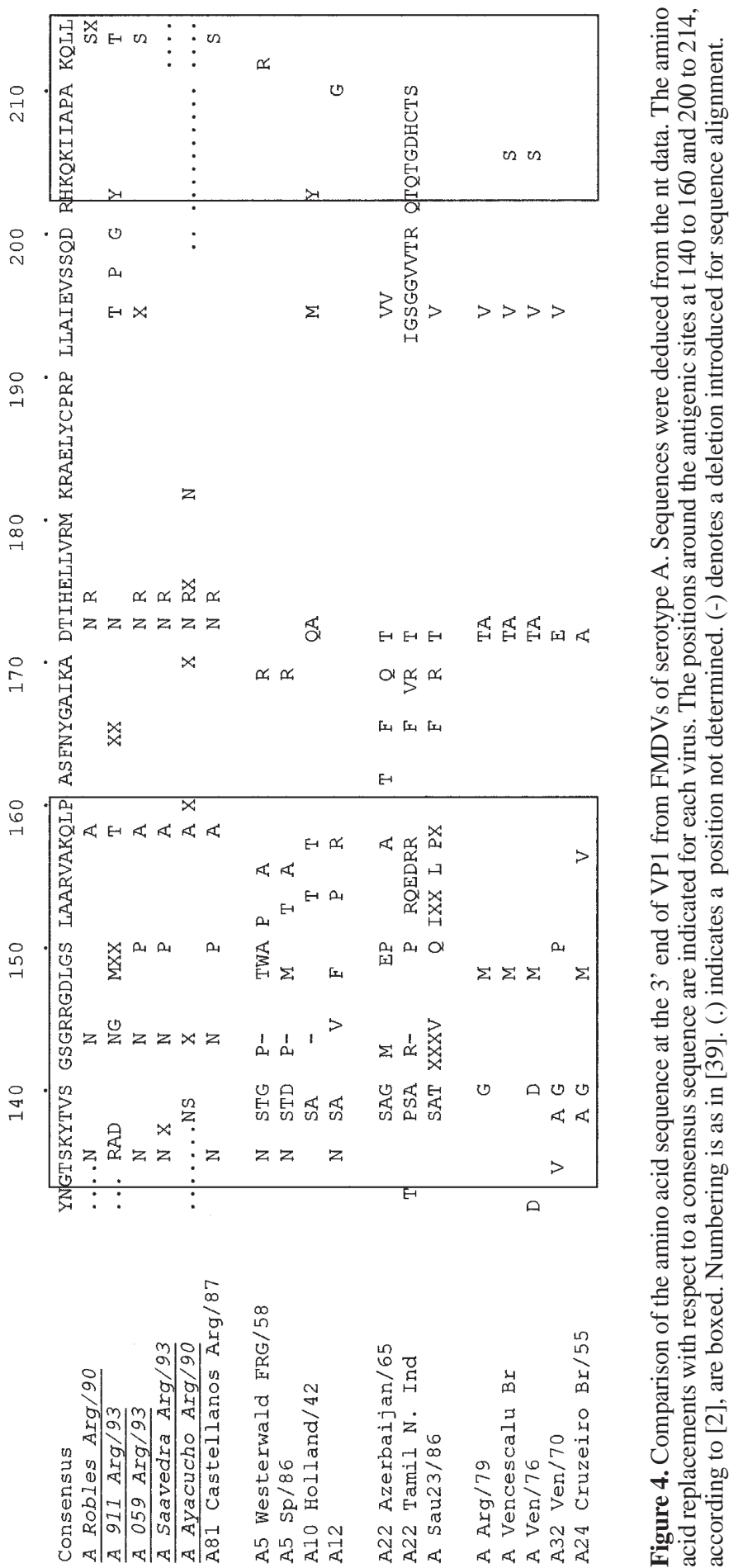


1)
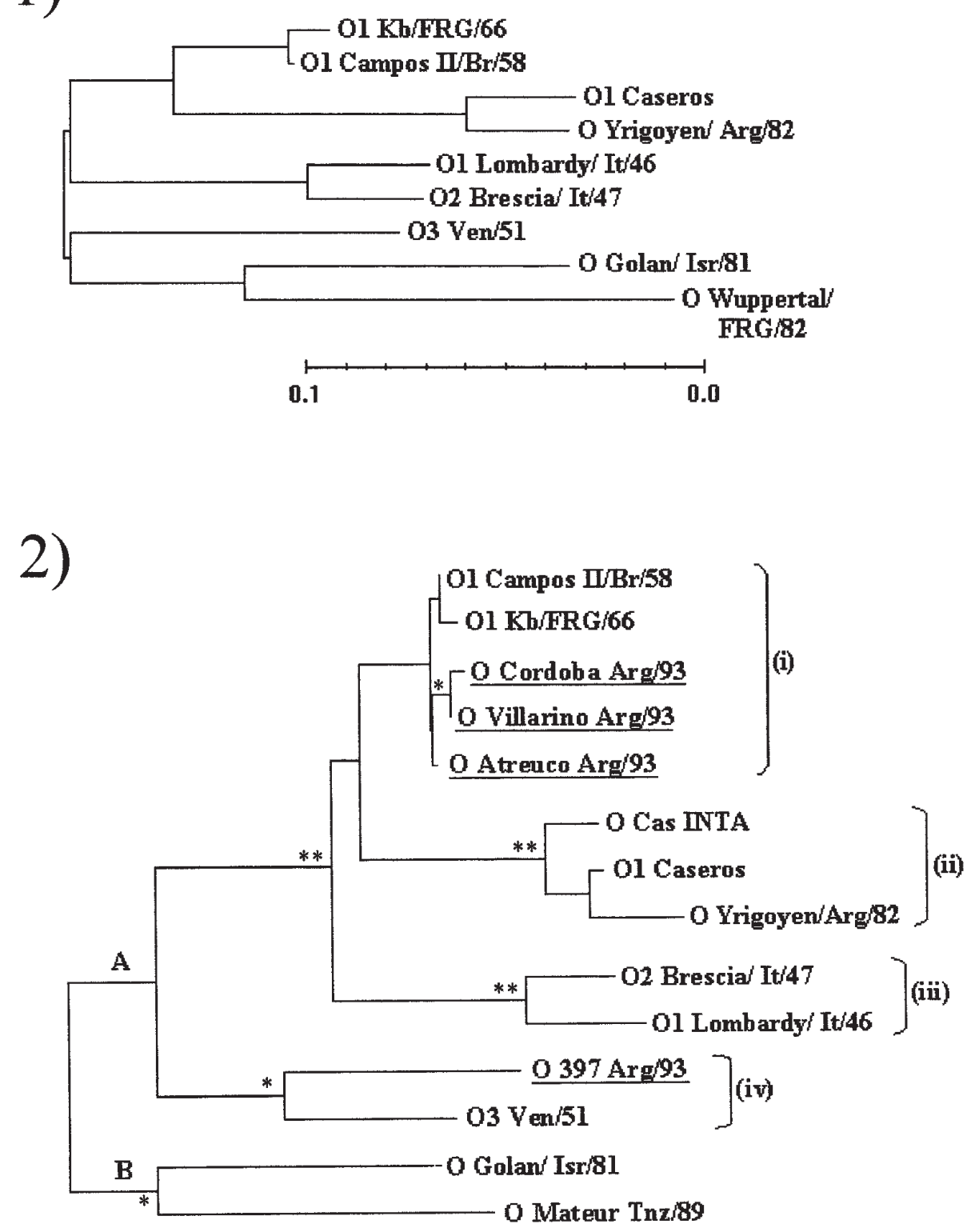

0.1

Figure 5. Phylogenetic trees derived from the type O VP1 gene sequences. (1) Tree corresponding to the whole VP1 gene (adapted from [23]). (2) Tree derived from the $250 \mathrm{nt}$ of the 3' end of type O VP1 sequences, including the Argentinean sequences determined in this work (underlined). Details are as in the legend of Figure 3. 


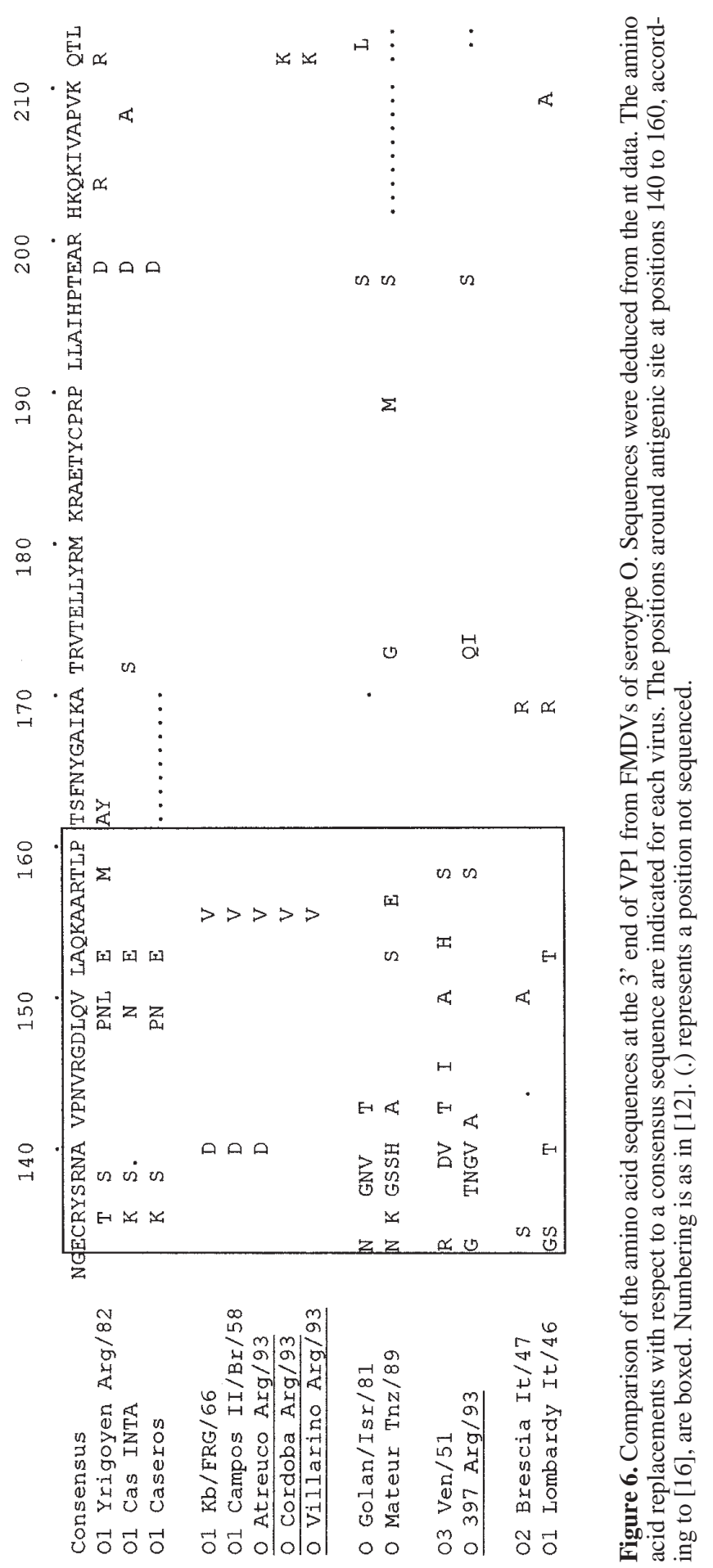


The results obtained with serotypes A and $\mathrm{O}$ confirmed that positions 400 to 650 , in spite of not being the most informative stretch of the VP1 gene, allowed derivation of phylogenetic trees with a topology closely similar to that of the trees derived from the whole gene.

\section{DISCUSSION}

An extensive set of VP1 sequences spanning the positions 150 to 250 from the 3' end of the VP1 gene of different FMDV serotypes has been obtained by different groups and is available for epidemiological studies. In this report, we showed that the VP1 region for serotypes $\mathrm{A}$ and $\mathrm{O}$, when compared to the whole gene, is predicted to contain lower phylogenetic information than other gene stretches, at the serotype level (Fig. 2). The prediction of the informative content used also indicates that windows $250 \mathrm{nt}$ upstream from the 3' end are more informative than the analysed shorter windows.

Our findings with types $\mathrm{A}$ and $\mathrm{O}$ differed from those obtained with type C FMDVs, in which windows spanning the 3 ' end region are predicted to contain higher informative values [22]. In spite of this observation, the information present in the 250 3 ' end nt of the gene was sufficient to reconstruct phylogenetic trees, including isolates representative of the viral diversity found in serotypes A and $\mathrm{O}$, with topologies similar to those of trees derived from the whole gene (Figs. 3 and 5) [9, 22, 23]. The rapid improvement of sequencing technology offers the possibility to extend FMDV sequencing analyses to the VP1 gene, and eventually to the four capsid protein (P1) genes. This is highly desirable, in view of the additional information that will be derived from these analyses. However, the results reported here, indicated that, for phylogenetic purposes, the use of windows of the 250 3' end nt allowed derivation of trees similar to those obtained with the whole
VP1 gene of serotypes $\mathrm{A}, \mathrm{O}$ and $\mathrm{C}$. This sequence window also offered the possibility of deducing the amino acid sequence corresponding to VP1 residues around positions $140-160$ and those at the carboxyterminus, which contribute to important antigenic sites in the three serotypes [2, 16, 25]. These results may provide additional information on the antigenic properties of the viral isolates.

An example of the usefulness of sequencing and phylogenetic analyses of the 3' end VP1 region is illustrated by the results obtained in the study of the viruses that circulated in Argentina between 1990 and 1993. During these years, a compulsory and extensive vaccination policy took place. This policy allowed the eradication of the disease in 1994. Therefore, the isolates analysed were among those that occurred in the final stages of this eradication campaign. The sequences of the type A isolates analysed were included with those of the representative virus in order to derive a detailed phylogenetic analysis of this serotype (Fig. 3). The serological diversity of serotype A is high, with more than 30 subtypes described. Some of these subtypes have circulated in the world in the last years, while others did not circulate during the last decades. The general features of the type A tree were consistent with those previously described for type $\mathrm{C}$ [24] and type $\mathrm{O}$ viruses [33]. Two main, independent lineages which correlated well with the geographical origin of the virus could be distinguished (Fig. 3). Lineage A included European viruses corresponding to serologic subtypes A5, A10 and A12. Lineage B contained most South American viruses, in which the remaining serologic subtypes were present.

The analysed Argentinean isolates were closely related to the A81 Castellanos Arg/87 vaccine strain, defining an independent cluster within lineage B. The main South American reference strains, including viruses that circulated in the field in the seventies as A Arg/79, appeared in different clusters of this lineage B. The high sequence 
homology observed between the Argentinean field isolates analysed and the A81 Castellanos Arg/87 vaccine strain, suggests that these isolates had a vaccine origin. This observation agreed with previous reports $[3,4]$ that associated the emergence of field outbreaks with the vaccine strains in use in areas of low incidence of the disease. Interestingly, Asiatic viruses such as A Azerbaijan/65, A22 Tamil Nadu Ind/90 and A Sau23/86, were located in the tree in an independent cluster within lineage B.

The comparison of the amino acid sequences deduced from the nt sequences showed that non-synonymous substitutions were accumulated around positions 140-160, which span a major antigenic site in this and other serotypes [2, 16, 25, 32]. In addition, substitutions were also found in the last residues of the protein, which constitute an additional antigenic site (Fig. 4). Even when a detailed antigenic characterisation of the analysed Argentinean viruses is not available, the genetic divergence of their sequences as well as the substitutions found in common in most of these viruses at VP1 positions 143,158 and 213 suggest that they may have specific antigenic properties.

The phylogenetic tree of type $\mathrm{O}$ isolates indicates that, conversely to what was found for type A, Argentinean isolates belonging to two different lineages were noticed. Isolates O Cordoba Arg/93, O Villarino Arg/93, and $\mathrm{O}$ Atreuco Arg/93 were closely related and were grouped in the cluster in which viruses that were used as vaccine strains in Europe and South America were located (Fig. 5). Among them, viral strains in use in Argentina in the 1980s-1990s, were included. In addition, as observed with the type A viruses analysed, these type $\mathrm{O}$ isolates were closely related to the vaccine strain O1 Campos Br/58. Conversely, the O 397 Arg/93 virus was located in a different lineage in the tree, close to the $\mathrm{O} 3 \mathrm{Ven} / 51$. Thus, a virus with a different genotype, related to the $\mathrm{O} 3$ subtype, co-circulated in Argentina with the viruses of clus- ter (i) in the final stage of the eradication campaign.

The amino acid comparison of the type $\mathrm{O}$ viruses analysed showed a good correlation between the genotype and the residues present in the 140-160 region and the carboxyterminus of VP1, which contribute to an important antigenic site in this serotype [16] (Fig. 6). Thus, the Argentinean viruses of cluster (i) shared common amino acid substitutions with respect to viruses belonging to other clusters.

The evolutionary patterns observed resemble those shown by FMDV isolates in Western Europe in the years previous to the cancellation of the vaccination policy campaign [3, 4, 24, 33]. The type A viruses and the type $\mathrm{O}$ viruses grouped in cluster (i) shared a high level of nt conservation. The quasispecies structure of FMDV populations implies the heterogeneous sequence composition of FMDV isolates [8], which makes the establishment of rigorous distinctions among highly related viruses difficult. This feature favours the interpretation that the Argentinean viruses were derived from vaccine strains in use at the time of their isolation.

In spite of these common features with FMDV evolution in Western Europe, viral circulation in Argentina seems to be more diversified since co-circulation of $\mathrm{O} 1$ and $\mathrm{O} 3$ viruses is documented. This observation probably reflects a higher complexity of FMDV epidemiology in South America.

\section{ACKNOWLEDGEMENTS}

Work at CBMSO-INIA was supported by CYCIT (grant BIO99-0833-C02-01), UE (grant CT97-3665) and Fundación Ramón Areces.

\section{REFERENCES}

[1] Armstrong R.M., Samuel A.R., Carpenter W.C., Kant R., Knowles N.J., A comparative study of serological and biochemical methods for strain 
differentiation of foot-and-mouth disease type A virus, Vet. Microbiol. 39 (1994) 285-298.

[2] Baxt B., Vakharia V.N., Moore D.M., Franke A.J., Morgan, D.O., Analysis of neutralizing antigenic sites on the surface of type A12 foot and mouth disease virus, J. Virol. 63 (1989) 21432151.

[3] Beck E., Strohmaier, K., Subtyping of european foot-and-mouth disease virus strains by nucleotide sequence determination, J. Virol. 61 (1987) 1621-1629.

[4] Carrillo C., Dopazo J., Moya A., González M., Martínez M.A., Sáiz J.C., Sobrino F., Comparison of vaccine strains and the virus causing the 1986 foot-and-mouth disease outbreak in Spain: an epizootiological analysis, Virus Res. 15 (1990) 4556.

[5] Cheung A., Delamater J., Weiss J., Küpper H., Comparison of the major antigenic determinants of different serotypes of foot-and-mouth disease virus, J. Virol. 48 (1983) 451-459.

[6] Dawe P.S., Flanagan F.O., Madekurozwa R.L., Sorensen K.J., Anderson E.C., Foggin C.M., Ferris N.P., Knowles N.J., Natural transmission of foot-and-mouth disease virus from African buffalo (Syncerus caffer) to cattle in a wildlife area of Zimbabwe, Vet. Rec. 134 (1994) 230-232.

[7] Domingo E., Mateu M.G., Martínez M.A., Dopazo J., Moya A., Sobrino F., Genetic variability and antigenic diversity of foot-and-mouth disease virus, in: Kurstak E., Marusyk R.G., Murphy S.A., Van-Regenmortel M.H.V. (Eds.), Applied virology research, Vol. 2, Virus variation and epidemiology, Plenum Publishing Corp., New York, 1990, pp. 233-266.

[8] Domingo E., Escarmís C., Martínez M.A. Martínez-Salas E., Mateu M.G., Foot-and-mouth disease virus populations are quasispecies, Curr. Top. Microbiol. Immunol. 176 (1992) 33-47.

[9] Dopazo J., Sobrino F., Palma E.L., Domingo E., Moya, A., Gene encoding capsid protein VP1 of foot-and-mouth disease virus: a quasispecies model of molecular evolution, Proc. Natl. Acad. Sci. USA 85 (1988) 6811-6815.

[10] Dopazo J., Rodrigo M.J., Rodríguez A., Sáiz J.C., Sobrino, F., Aphthovirus evolution, in: Gibbs A., García-Arenal F., Calisher C.H. (Eds.), Molecular evolution of viruses, Cambridge University Press, 1995, pp. 310-320.

[11] Felsenstein J., Confidence limits on phylogenies: an approach using the boostrap, Evolution 39 (1985) 783-791.

[12] Forss S., Strebel K., Beck E., Schaller, H., Nucleotide sequence and genome organization of foot-and-mouth disease virus, Nucleic Acids Res. 2 (1984) 6587-6601.

[13] Higgins D., Bleasby A., Fuchs R., Clustal V: improved software for multiple sequence alignment, CABIOS 8 (1992) 189-191.
[14] Kitching R.P., A recent history of foot-and-mouth disease virus, J. Comp. Pathol. 118 (1998) 89108

[15] Kitching R.P., Knowles N.J., Samuel A.R., Donaldson A.I., Development of foot-and-mouth disease virus strain characterization - a review, Trop. Anim. Health Prod. 21 (1989) 153-166.

[16] Kitson J.D.A., Mc Cahon D., Belsham G.J., Sequence analysis of monoclonal antibody resistant mutant of type $\mathrm{O}$ foot-and-mouth disease virus: Evidence for the involvement of the three surface exposed capsid protein in four antigenic sites, Virology 179 (1990) 26-34.

[17] Krebs O., Berger H.-G., Marquardt O., The capsid protein-encoding region of foot-and-mouth disease virus O2 Brescia, Arch. Virol. 120 (1991) 135-143.

[18] Krebs O., Berger H.-G., Niedbalski W., Marquardt O., Foot-and-mouth disease virus O1 Lombardy is biochemically related to $\mathrm{O} 2$ isolates, Virus Genes 5 (1991) 255-266.

[19] Leister D., Adam K.H., Marquardt O., Co-replication of several isotypes of foot-and-mouth disease virus, J. Gen. Virol. 74 (1993) 2753-2757.

[20] Makoff A.J., Paynter C.A., Rowlands D.J., Boothroyd J.C., Comparison of the amino acid sequence of the major immunogen from three serotypes of foot-and-mouth disease virus, Nucleic Acids Res. 10 (1982) 8285-8295.

[21] Marquardt O., Haas B., VP1-coding sequences in recent isolates of foot-and-mouth disease virus types A, O and Asia1, Virus Genes 16 (1998) 185-193.

[22] Martín M.J., González-Candelas F., Sobrino F., Dopazo J., A method for determining the position and size of optimal sequence regions for phylogenetic analysis, J. Mol. Evol. 41 (1995) 11281138.

[23] Martín M.J., Núñez J.I., Sobrino F., Dopazo J., A procedure for detecting selection in highly variable viral genomes: evidence of positive selection in antigenic regions of capsid protein VP1 of foot-and-mouth disease virus, J. Virol. Methods 74 (1998) 215-221.

[24] Martínez M.A., Dopazo J., Hernández J., Mateu M.G., Sobrino F., Domingo E., Knowles N.J., Evolution of capsid protein genes of foot-andmouth disease virus: antigenic variation without accumulation of amino acid substitutions over six decades, J. Virol. 66 (1992) 3557-3565.

[25] Mateu M.G., Antibody recognition of picornaviruses and escape from neutralization: a structural view, Virus Res. 38 (1995) 1-24.

[26] Mbayed V., Schiappacassi M., Corominas A., Campos R., Characteristic in vitro evolution pattern of foot-and-mouth disease virus A81/Castellanos/Arg/87, Virus Res. 48 (1997) 157-163.

[27] Pattnaik B., Venkataramanan R., Tosh C., Sanyal A., Hemadri D., Samuel A.R., Knowles N.J., Kitching R.P., Genetic heterogeneity of Indian field isolates of foot-and-mouth disease virus 
serotype $\mathrm{O}$ as revealed by partial sequencing of 1D gene, Virus Res. 55 (1998) 115-127.

[28] Pereira H.G., Foot-and-mouth disease, in: Gibbs E.P.J. (Ed.). Virus disease of food animals, Vol. 2, Academic Press Inc., London, 1981, pp. 333-363.

[29] Rieder Rojas E., Carrillo E, Schiappacassi M., Campos R., Modification of foot-and-mouth disease virus $\mathrm{O} 1 \mathrm{Caseros}$ after serial passages in the presence of antiviral polyclonal sera, J. Virol. 66 (1992) 3368-3372.

[30] Robertson B.H., Grubman M.J., Weddell G.N., Moore D.M., Welsh J.D., Fisher T., Dowbenko D.J., Yansura D.G., Small B., Kleid, D.G., Nucleotide and amino acid sequence coding for polypeptides of foot-and-mouth disease virus type A12, J. Virol. 54 (1985) 651-660.

[31] Saitou N., Nei M., The neighbour-joining method: a new method for reconstructing phylogenetic trees, Mol. Biol. Evol. 241 (1987) 425-436.

[32] Sáiz J.C., González M.J., Borca M.V., Sobrino F., Moore D.M., Identification of neutralizing antigenic sites on VP1 and VP2 of type A5 footand-mouth disease virus defined by neutralizing resistant variants, J. Virol. 65 (1991) 2518-2524.

[33] Sáiz J.C., Sobrino F., Dopazo J., Molecular evolution of foot-and-mouth disease virus type $\mathrm{O}, \mathrm{J}$. Gen. Virol. 74 (1993) 2281-2285.

[34] Samuel A.R., Knowles N.J., Kitching R.P., Hafez S.M., Molecular analysis of foot-and-mouth dis- ease type $\mathrm{O}$ viruses isolated in Saudi Arabia between 1983 and 1995, Epidemiol. Infect. 119 (1997) 381-389.

[35] Samuel A.R., Knowles N.J., Mackay D.K., Genetic analyses of type $\mathrm{O}$ viruses responsible for epidemics of foot-and-mouth disease in North Africa, Epidemiol. Infect. 122 (1999) 529-538.

[36] Taboga O., Tami C., Carrillo E., Núñez J.I., Rodríguez A., Sáiz J.C., Blanco E., Valero M.L., Roig X., Camarero J.A., Andreu D., Mateu M.G., Giralt E., Domingo E., Sobrino F., Palma E.L., A large scale evaluation of peptide vaccines against foot-and-mouth disease: lack of solid protection in cattle and isolation of scape mutants, J. Virol. 71 (1997) 2606-2614.

[37] Thomas A.A.M., Woortmeijer R.J., Puijk W., Barteling S.J., Antigenic sites on foot-and-mouth disease virus type A10, J. Virol. 62 (1988) 27822789.

[38] Vosloo W., Knowles N.J., Thomson G.G., Genetic relationships between southern African SAT-2 isolates of foot-and-mouth disease virus, Epidemiol. Infect. 109 (1992) 547-558.

[39] Weddell G.N., Yansura D.G., Dowbenko D.J., Hoatlin M.E., Grubman M.J., Moore D.M., Kleid D.G., Sequence variation in the gene of the immunogenic capsid protein VP1 of foot-andmouth disease virus type A, Proc. Natl. Acad. Sci. USA 82 (1985) 2618-2622. 